DOI: https://doi.org/10.24127/ajpm.v9i3.2956

\title{
DEFRAGMENTING PROSES BERPIKIR PSEUDO SISWA DALAM MENYELESAIKAN MASALAH MATEMATIKA
}

\author{
Junaidi Fery Efendi ${ }^{*}$, Ryan Angga Pratama \\ ${ }^{1}$ Pendidikan Matematika, Universitas Muhammadiyah Surabaya, Indonesia \\ ${ }^{2}$ Pendidikan Matematika, Universitas Balikpapan, Indonesia \\ *Corresponding author. Jl. Raya Sutorejo No.59, Dukuh Sutorejo, Kota Surabaya, Jawa Timur 60113 \\ E-mail: $\quad$ junaidi.fery@fkip.um-surabaya.ac.id ${ }^{\left.{ }^{*}\right)}$ \\ ryan.angga@uniba-bpn.ac.id ${ }^{2)}$
}

Received 19 July 2020; Received in revised form 09 September 2020; Accepted 26 September 2020

\begin{abstract}
Abstrak
Penelitian ini bertujuan untuk melihat proses berpikir pseudo salah atau benar serta melihat dan melakukan defragmenting dalam menata kembali kesalahan proses berpikir siswa. Penelitian ini menggunakan pendekatan kualitatif deskriptif dengan pengambilan subjek penelitian sebanyak 11 siswa kelas IX SMP Muhammadiyah 10 Surabaya. Teknik pengumpulan data dengan lembar soal tes dilanjutkan dengan wawancara, kemudian dianalisis dan dideskripsikan. Hasil penelitian menunjukkan siswa mengalami pseudo salah dimana jawaban salah namun setelah refleksi siswa mampu memberikan jawaban yang benar. Pada proses berpikir pseudo ini siswa mengalami kesalahan mengkontruksi konsep matematika, kesalahan berpikir analogi dan kesalahan penempatan konsep matematika. Tahapan yang dilakukan dalam menata kembali proses berpikir pseudo maka dilakukan defragmenting yaitu dengan memberikan scaffolding, conflict cognitive dan disequilibrasi. Hasil yang diperoleh dalam defragmenting siswa mampu mengkontruksi, menganalogi dan menempatkan konsep matematika secara terstruktur.
\end{abstract}

Kata kunci: conflict cognitive; defragmenting; disequilibrasi; pseudo; scaffolding.

\begin{abstract}
The purpose of this research is to see the right or wrong of pseudo thinking process, also to see and do defragmenting in rearranging students' thinking process errors. This study used a descriptive qualitative approach by taking 11 research subjects of students in class IX Muhammadiyah 10 School. Data collection techniques with test questions continued with interviews, then analyzed and described. The results showed students experienced wrong pseudo where the answers were wrong, but after reflection students were able to give correct answers. In this pseudo thinking process students have errors experience to constructing mathematical concepts, analogical thinking errors and placement errors of mathematical concepts. The steps taken to restructure the pseudo thinking process are carried out by defragmenting, that are providing scaffolding, cognitive conflict and disequilibration. The results obtained in defragmenting students are able to construct, analogize and placement of mathematical concepts in a structured and correct manner.
\end{abstract}

Keywords: conflict cognitive; defragmenting; disequilibrasi; pseudo; scaffolding.

This is an open access article under the Creative Commons Attribution 4.0 International License

\section{PENDAHULUAN}

Proses berpikir merupakan respon pikiran terhadap informasi yang diterima (Ormrod, 2009). Dalam kegiatan proses berpikir sering kali terjadi kesahalahan baik secara konsep, prinsip, operasi dan kecerobohohan.
Kesalahan proses berpikir ini disebabkan kurangnya pemahaman materi prasyarat yang dipahami, sehingga tidak teliti dalam perhintungan matematika (Badaruddin et al., 2016; Wulandari, 2018). Kesalahan dalam menyelesaikan masalah matematika 
bisa dijadikan tolak ukur kemampuan siswa dalam memahami materi, serta dapat menganalisis langkah perbaikan yang akan dilakukan (Siswandi, 2016). Kesalahan dalam proses berpikir ini disebabkan karena tidak memahami makna terkait konsep penyelesaian matematika dan cenderung menghafal konsep (Pujilestari, 2018; Vilianti et al., 2018) Kesalahan proses berpikir merupakan penyimpangan dalam menyelesaikan masalah matematika.

Hal menarik dalam pembelajaran matematika tentang cara siswa mengkontruksi antarkonsep yang sudah dimiliki sebelumnya dan mengaitkan dengan konsep baru yang dimiliki dalam menyelesaikan masalah matematika. Proses mengkontruksi inilah yang sering kali terjadi kesalahan dalam tahapan berpikir siswa, sedangkan pemahaman mengaitkan antara konsep yang dianggap benar inilah yang kemudian disebut berpikir pseudo seolah-olah konsep yang sudah dikaitkan dianggap benar namun realitasnya kurang tepat. Konsep pseudo pertama kali dimunculkan oleh Vinner pada tahun 1997.

Siswa yang melakukan pseudo berpikir bisa terlihat dari cara mengkontruksi konsep yang salah dari reaksi spontan dalam menyelesaikan masalah, tidak fleksibel dan tidak terkontrol. Pemahaman konsep yang dimiliki terlihat dangkal dan semu yaitu bisa menjawab soal dengan mudah namun lemah dalam menyampaikan keterkaitan konsep yang berkaitan dengan konsep baru yang dijelaskan (Sopamena et al., 2018; Wibowo et al., 2018). Melihat kesalahan mendasarkan yang dilakukan oleh siswa maka perlu menata kembali kaitan antarkonsep sehingga menjadi kesatuan utuh yang tepat dan tidak terlihat semu.
Kesalahan mendasar yang sering kali dilakukan siswa belum mampu menghubungkan skema proses berpikir dalam mengaitkan konsep dengan penyelesaian masalah. Menurut (Subanji \& Nusantara, 2016) proses mengaitkan konsep dengan masalah, diantaranya: (1) pseudo konstruksi yang merupakan jawaban semu seolah-olah benar namun secara konseptual salah, meskipun setelah refleksi siswa dapat menerangkan secara tepat, (2) konstruksi terhadap struktur dalam skema pemahaman yang muncul namun belum terkontruksi dengan benar, (3) kesalahan berpikir logis muncul melihat asumsi struktur konsep pemikiran seolah-olah dianggap benar namun pada realitanya salah dan tidak sesuai dengan konsep, serta (4) kesalahan berpikir analogi ketika memberikan analogi berdasarkan asumsi dengan jawaban tidak tepat.

Penelitian sebelumnya dalam mengungkapkan kesesalahan berpikir siswa dalam memecahkan masalah matematika (Indri \& Widiyastuti, 2018; Yani et al., 2016) : (1) Kesulitan yang dialami oleh siswa dalam menyelesaikan masalah lupa terhadap konsep, makna soal yang diberikan serta kurang teliti dalam mengerjakan soal. (2) kesalahan siswa dalam memahami masalah matematika terbagi menjadi 3 tingkatan rendah, sedang dan tinggi. Kesalahan dalam berpikir dikarenakan mengalami pseudo-analitik dan pseudosalah. (3) kesalahan dalam melaksanakan rencana penyelesaian terjadi dikarenakan ketidaklengkapan proses.

Kesalahan proses berpikir siswa perlu mendapatkan perhatiaan agar kesalahan konsep tidak berdampak pada konsep berikutnya. Proses defragmenting terhadap berpikir pseudo siswa perlu diketahui seberapa jauh 
DOI: https://doi.org/10.24127/ajpm.v9i3.2956

kesalahan konsep yang dilakukan oleh siswa. Penelitian ini juga melakukan peta kognitif agar dapat menggambarkan hubungan sebab akibat permasalahan yang diangkat. Proses berpikir dalam konteks pemahaman konsep menjadi acuan mengukur kualitas dan kuantitas antara konsep prasyarat yang akan digunakan dikonsep matematika berikutnya.

Kesalahan proses berpikir pada struktur berpikir dapat diselaikan dengan cara menata kembali proses berpikir yang salah, salah satunya adalah dengan defragmenting. Defragmenting merupakan restrukturisasi cara berpikir dengan pemahaman yang dalam dan lengkap (Wibawa et al., 2017). Penataan ulang ini dilakukan dengan cara melihat kesalahan mendasar dengan melihat jawaban siswa terhadap soal. Proses ini mampu memperlihatkan kepada siswa pada langkah apa yang terjadi kesalahan agar siswa paham akan kesalahan dan cara pembenaran sehingga didapatkan solusi yang diinginkan.

Menurut (Haryanti, 2018), defragmenting dapat dilakukan dengan beberapa langkah, diantaranya: (1) Scanning yang merupakan gambaran peta kognitif dalam menyelesaikan masalah berdasarkan proses berpikir siswa, (2) Chek some errors merupakan proses untuk melihat ketidaktepatan siswa dalam memahami persoalan, (3) Repairing merupakan penataan yang dilakukan sesuai dengan tingkat kesalahan pemahaman yang dilakukan, (4) Give a chance to re-work merupakan kesempatan yang diberikan kembali kepada sisswa untuk mengerjakan kembali masalah yang telah diberikan, (5) Certain the result merupakan tahapan untuk memastikan kembali jawaban yang benar serta tingkat pemahaman konsep terhadap masalah yang telah dikerjakan.

Sejalan dengan hal tersebut, (Yuwono et al., 2018) mengungkapkan bahwa salah satu pemecahan masalah pada proses berpikir siswa dapat diselesaikan dengan Tahapan Polya, yakni: (1) mengidentifikasi masalah yang muncul serta konsep yang bisa digunakan, (2) membuat rencana siswa agar dapat merancang konsep yang akan digunakan untuk memecahkan masalah yang akan dihadapi, (3) menggunakan konsep yang telah dirancang untuk menyelesaikan masalah, (4) memeriksa kembali konsep yang telah diterapkan dan mempertimbangkan apakah solusi yang telah dibuat logis dan utuh.

Proses defragmenting ini dilakukan secara bertahap dengan melihat seberapa besar tingkat kesalahan dalam proses berpikir dan dapat direstrukturisasi kembali menjadi pemahaman yang utuh. Dalam hal ini proses defragmenting yang dilakukan adalah disequilibrasi, conflict cognitive, serta scaffolding (Kirnasari et al., 2016).

Pemahaman konsep yang akan digunakan dalam menata struktur berpikir siswa menjadi bagian penting dalam deftragmenting. Merangkai kembali konsep yang terputus menjadi satu kesatuan untuk mendapatkan jawaban dan penjelasan yang benar dan tepat. Dalam penataan tersebut perlu pemahaman relasional antar konsep yang terkait dengan yang lain, sehingga proses kontruksi dalam pemahaman konsep menjadi bermakna (Kennedy, 2008).

Dengan memperlihatkan perbedaan hasil penelitian sebelumnya dengan uraian latar belakang, penelitian berfokus pada defragmenting proses pseudo berpikir siswa dalam menyelesaikan masalah matemaika dengan melihat masalah berpikir secara 
utuh tentang kontruksi konsep, berpikir analogi, penempatan konsep dan pseudo konsep matematika. Serta melakukan defragmenting dengan tahapan polya. Oleh karena itu, disimpulkan bahwa tujuan dari penelitian ini adalah untuk melihat proses berpikir pseudo salah atau benar serta melihat dan melakukan defragmenting dalam menata kembali kesalahan proses berpikir siswa.

\section{METODE PENELITIAN}

Penelitian ini merupakan penelitian kualitatif dengan jenis deskriptif. Penelitian deskriptif kualitatif digunakan untuk mendapatkan gambaran tentang pseudo berpikir siswa dan proses defragmanting penyelesaian masalah siswa. Penelitian ini dipilih dalam rangka untuk melakukan analisis secra mendalam sehingga dapat menghasil hasil yang maksimal serta sesuai dengan tujuan dari penelitian.

Secara garis besar penelitian ini terdiri dari tiga tahapan, tahapan pertama adalah persiapan penelitian, tahapan kedua pelaksanaan kegiatan penelitian yang dilakukan pada siswa kelas IX SMP Muhammadiyah 10 Surabaya dan tahapan ketiga adalah analisis data hasil penelitian. Subjek penelitian berjumlah sebanyak 11 siswa yang nantinya akan dipilih berdasarkan tingkat kesalahan dalam menjawab soal pada materi Operasi Bilangan Bulat serta Akar dan Pangkat, dimana setiap siswa yang dipilih akan dilakukan defragmanting berdasarkan kesalahan berpikir dalam menjawab soal yang telah diberikan.

Instrumen penelitian terdiri dari soal tes dalam bentuk uraian sebanyak tiga soal yang telah dibuat dan divalidasi kepada expert judgement (validator ahli) dalam hal ini Dosen Pendidikan Matematika Universitas
Muhammadiyah Surabaya. Instrumen kedua adalah Pedoman Wawancara yang berisi garis-garis besar pertanyaan terstrukur untuk mendapatkan data berpikir pseudo siswa secara komprehensif.

Hasil data yang diperoleh akan dianalisis berdasarkan hasil tes soal dengan langkah-langkah sebagai berikut:

1. Menganalisis indikator pseudo berpikir berdasarkan jawaban yang telah diberikan

2. Menyajikan hasil analisis kedalam bentuk teks naratif

3. Membuat kesimpulan berdasarkan indikator berpikir pseudo siswa.

Adapun analisis hasil yang digunakan bedasar pada tahapan Polya, pertama tingkat pemahaman subjek dalam melihat masalah, kedua subjek dapat menyusun rencana penyelesaian masalah, ketiga subjek dapat melakasanakan penyelesaian masalah dan keempat subjek dapat memeriksa kembali penyelesaian yang diberikan.

Hasil wawancara akan dianalis untuk memperkuat hasil tes agar data yang diperoleh dilihat tingkat kesalahan konsep yang telah dilakukan oleh siswa. Sehingga ketika dilakukan defragmenting lebih terstruktur dan terarah. Untuk memeriksa keabsahan hasil wawancara maka dilakukan beberapa tahap, diantaranya: (1) tahap reduksi memeriksa kembali hasil wawancara dan menyajikan hasil sesuai dengan kebutuhan penelitian, (2) menyajikan data yaitu dengan mengidentifikasi data proses berpikir pseudo siswa dan manarik kesimpulan. (3) menarik kesimpulan dilakukan dengan mengkategorikan berdasarkan kemampuan siswa menjawab disesuaikan dengan tahapan Polya pada Tabel 1. 
DOI: https://doi.org/10.24127/ajpm.v9i3.2956

Tabel 1. Indikator Penarikan Kesimpulan Menurut Polya

\begin{tabular}{|c|c|}
\hline Penarikan Kesimpulan & Indikator \\
\hline \multirow{3}{*}{$\begin{array}{l}\text { Subjek dapat dikatakan } \\
\text { memahami masalah }\end{array}$} & 1) Siswa memahami soal yang diberikan \\
\hline & $\begin{array}{l}\text { Siswa mengungkapkan yang diketahui dan yang } \\
\text { ditanyakan dari soal yang diberikan. }\end{array}$ \\
\hline & $\begin{array}{l}\text { 3) Siswa memahami kecukupan informasi terhadap } \\
\text { pertanyaan. }\end{array}$ \\
\hline \multirow[t]{2}{*}{$\begin{array}{l}\text { Subjek dapat } \\
\text { menyusun } \\
\text { penyelesaian }\end{array}$} & $\begin{array}{l}\text { 1) Siswa mampu menemukan kemiripan menjawan } \\
\text { masalah yang akan dijadikan acuan dalam } \\
\text { menjawab masalah yang diberikan. }\end{array}$ \\
\hline & $\begin{array}{l}\text { 2) Siswa mampu menentukan rumus yang digunakan } \\
\text { dalam menjawab masalah. }\end{array}$ \\
\hline \multirow{5}{*}{$\begin{array}{l}\text { Subjek dapat dikatakan } \\
\text { melaksanakan penyelesaian } \\
\text { Subjek dapat dikatakan } \\
\text { memeriksa kembali }\end{array}$} & Siswa dapat menyelesaikan soal sesuai rencana \\
\hline & 2) Siswa dapat menggunakan tahapan secara teratur \\
\hline & $\begin{array}{l}\text { 1) Siswa dapat memriksa ketepatan langkah yang } \\
\text { digunakan }\end{array}$ \\
\hline & 2) Siswa memeriksa kembali hasil yang didapatkan \\
\hline & 3) Siswa menyimpulkan hasil yang didapatkan \\
\hline
\end{tabular}

\section{HASIL DAN PEMBAHASAN}

Data yang akan dianalisis adalah siswa yang mengalami berpikir pseudo matematika pada materi Operasi Bilangan Bulat serta Akar dan Pangkat. Sebelum dilakukan pengumpulan data persiapan dengan pembuatan soal uraian yang digunakan untuk melihat kesalahan cara berpikir pada siswa. Data yang diperoleh dari lapangan kemudian dilanjutkan dan dipilah berdasarkan tingkat kesalahan berpikir pseudo. Hasil ini dilanjutkan dengan penguatan wawancara yang dilakukan kepada siswa untuk mengetahui secara utuh kesalahan konsep siswa.

Hasil intrumen tes uraian pada 11 siswa menunjukkan bahwa soal pertama terjadi kesalahan dalam mengkontruksi konsep matematika secara mendasar, soal kedua beberapa siswa merasa bahwa jawabannya sudah benar namun secara konsep masih salah. Soal ketiga siswa terlihat mengalami kesalahan penempatan konsep matematika. Dari beberapa kesalahan yang dilakukan oleh siswa ada 5 anak yang mengalami kesalahan konsep namun masih dalam tahapan wajar sehingga mereduksi menjadi 3 siswa yang mengalami berpikir pseudo serta memiliki kemiripan kesalahan yang sama.

Dari hasil penentuan subjek penelitian maka dilakukan wawancara secara mendalam terkait kesalahan konsep yang dilakukan dalam menyelesaikan materi aljabar.

1. Kesalahan berpikir pseudo dalam mengkontruksi konsep matematika

Kesalahan konstruksi matematika yang dilakukan oleh siswa terlihat ketika menjawab pada intrument penelitian soal pertama $3 \times 2+2=$ $3 \times(2+2)$ jawaban siswa benar. Disini siswa terlihat mengalami berpikir pseudo karena hanya mengingat sifat operasi campuran, yaitu sifat komutatif $a+b=b+a$ atau $a \times b=b \times a$ padahal seharusnya adalah sifat distributif $a \times(b+c)=a b+a c$ maka seharusnya jawaban yang digunakan oleh siswa adalah salah 
DOI: https://doi.org/10.24127/ajpm.v9i3.2956

bukan benar. Disinilah terjadi kesalahan konsep berpikir siswa yang menunjukkan kebenaran semu.

2. Kesalahan berpikir analogi dalam konsep matematika

Kesalahan konsep berpikir analogi terlihat pada soal kedua yaitu $(a+$ $b)^{2}=a^{2}+b^{2}$ siswa menjawab benar, disini siswa terjadi kesalahan dalam menganalogikan pada bilangan bulat, sedangkan seharunya merupakan operasi pada bilangan akar dengan pengoperasian yang berbeda seharusnya $(a+b)^{2}=a^{2}+2 a b+b^{2}$. Jawaban siswa yang menyatakan benar seharunya jawaban yang tepat adalah salah.

3. Kesalahan menempatkan konsep matematika

Keselahan menempatkan konsep matematika terlihat pada soal ketika menjawab $\sqrt{x+y}=\sqrt{x}+\sqrt{y}$ siswa menjawa salah. Siswa hanya melihat konsep secara sederhana, konsep untuk operasi penjumlahan disamakan dengan penjumlahan bentuk akar yang harsunya $2 \sqrt{x}=\sqrt{x}+\sqrt{x}$ hal ini terlihat dari kesalahan penempatan konsep dan apabila dibiarkan akan mengakibatkan kesalahan fatal dalam konsep akar.

\section{Defragmenting berpikir pseudo konsep matematika}

Melihat ketiga kesalahan berpikir pseudo maka perlu dilakukan defragmenting untuk menjelaskan kepada siswa letak kesalahan dan menata kembali pemahaman yang salah. Hasil dari defragmenting berdasarkan tahapan polya disajikan pada Tabel 2 .

Tabel 2. Proses berpikir pseudo dan defragmenting, serta hasilnya.

\begin{tabular}{|c|c|c|c|c|}
\hline \multirow{2}{*}{ Tahapan polya } & \multirow{2}{*}{ Soal } & \multicolumn{3}{|c|}{ Berpikir pseudo dan defragmenting } \\
\hline & & Pseudo & Defragmenting & Hasil \\
\hline \multirow[t]{3}{*}{$\begin{array}{l}\text { Memahami } \\
\text { masalah }\end{array}$} & $3 \times 2+2=3 \times(2+2)$ & $\begin{array}{lr}\text { Kurang } & \\
\text { memahami } & \\
\text { konstruksi } & \text { sifat- } \\
\text { sifat } & \text { opesai } \\
\text { campuran } & \end{array}$ & $\begin{array}{l}\text { Pemberian } \\
\text { scaffolding } \\
\text { terkait } \\
\text { penggunaan } \\
\text { sifat-sifat } \\
\text { operasi } \\
\text { campuran }\end{array}$ & $\begin{array}{lr}\text { Subjek telah } \\
\text { memahami sifat } \\
\text { distributif pada } \\
\text { soal tersebut }\end{array}$ \\
\hline & $(a+b)^{2}=a^{2}+b^{2}$ & $\begin{array}{l}\text { Kurang } \\
\text { memahami } \\
\text { analogi antara } \\
\text { bilangan bulat } \\
\text { denga bilanga } \\
\text { berpangkat }\end{array}$ & $\begin{array}{l}\text { Pemberian } \\
\text { scaffolding } \\
\text { terkait } \\
\text { perbedaan } \\
\text { operasi pada } \\
\text { biangan bulat } \\
\text { dan bilangan } \\
\text { berpangkat }\end{array}$ & $\begin{array}{l}\text { Subjek dapat } \\
\text { mengungkapkan } \\
\text { perbedaan } \\
\text { operasi bilangan } \\
\text { bulat dan } \\
\text { bilangan } \\
\text { berpangkat }\end{array}$ \\
\hline & $\sqrt{x+y}=\sqrt{x}+\sqrt{y}$ & $\begin{array}{l}\text { Kesalahan dalam } \\
\text { menempatkan } \\
\text { konsep bilangan } \\
\text { bentuk akar }\end{array}$ & $\begin{array}{l}\text { Pemberian } \\
\text { scaffolding } \\
\text { terkait } \\
\text { perbedaan } \\
\text { operasi pada } \\
\text { biangan bentuk } \\
\text { akar }\end{array}$ & $\begin{array}{l}\text { Subjek dapat } \\
\text { mengungkapkan } \\
\text { perbedaan } \\
\text { operasi bilangan } \\
\text { bulat dan } \\
\text { bilangan bentuk } \\
\text { akar }\end{array}$ \\
\hline
\end{tabular}


AKSIOMA: Jurnal Program Studi Pendidikan Matematika

DOI: https://doi.org/10.24127/ajpm.v9i3.2956

\begin{tabular}{|c|c|c|c|c|}
\hline \multirow{2}{*}{ Tahapan polya } & \multirow{2}{*}{ Soal } & \multicolumn{3}{|c|}{ Berpikir pseudo dan defragmenting } \\
\hline & & Pseudo & Defragmenting & Hasil \\
\hline \multirow[t]{3}{*}{$\begin{array}{l}\text { Merencanakan } \\
\text { pemecahan } \\
\text { masalah }\end{array}$} & $3 x 2+2=3 x(2+2)$ & $\begin{array}{l}\text { Konsep prasyarat } \\
\text { tidak dipahami } \\
\text { dengan benar dan } \\
\text { penggunaan } \\
\text { penyelesaian yang } \\
\text { bisasa digunakan } \\
\text { sebelumnya }\end{array}$ & $\begin{array}{l}\text { Pemberian } \\
\text { scaffolding } \\
\text { terkait } \\
\text { penggunaan } \\
\text { informasi- } \\
\text { informasi terkati }\end{array}$ & $\begin{array}{l}\text { Mampu } \\
\text { merangcang } \\
\text { penyelesaian } \\
\text { berdasarkan } \\
\text { informasi yang } \\
\text { ada }\end{array}$ \\
\hline & $(a+b)^{2}=a^{2}+b^{2}$ & $\begin{array}{l}\text { Penyelesaian soal } \\
\text { sebagaimana } \\
\text { prosedur seuai } \\
\text { dengan } \\
\text { pemecahan yang } \\
\text { sederhana }\end{array}$ & $\begin{array}{l}\text { Pemberian } \\
\text { scaffolding } \\
\text { terkait tentang } \\
\text { tahapan operasi } \\
\text { bilangan } \\
\text { berpangkat }\end{array}$ & $\begin{array}{l}\text { Mampu } \\
\text { mengaitkan } \\
\text { konsep yang ada } \\
\text { dengan soal }\end{array}$ \\
\hline & $\sqrt{x+y}=\sqrt{x}+\sqrt{y}$ & $\begin{array}{l}\text { Penyelesaian soal } \\
\text { sebagaimana } \\
\text { prosedur seuai } \\
\text { dengan } \\
\text { pemecahan yang } \\
\text { sederhana }\end{array}$ & $\begin{array}{l}\text { Pemberian } \\
\text { scaffolding } \\
\text { terkait tentang } \\
\text { tahapan operasi } \\
\text { bilangan bentuk } \\
\text { akar }\end{array}$ & $\begin{array}{l}\text { Mampu } \\
\text { mengaitkan } \\
\text { konsep yang ada } \\
\text { dengan soal }\end{array}$ \\
\hline \multirow[t]{3}{*}{$\begin{array}{c}\text { Melaksanakan } \\
\text { perencanaan } \\
\text { masalah }\end{array}$} & $3 x 2+2=3 x(2+2)$ & $\begin{array}{l}\text { Kurangya } \\
\text { komitmen } \\
\text { kognitif yang } \\
\text { mengakibatkan } \\
\text { mudah menyerah } \\
\text { dan sangat } \\
\text { sederhana dalam } \\
\text { menyelesaiakan } \\
\text { masalah yang ada }\end{array}$ & $\begin{array}{l}\text { Pemberian } \\
\text { conflict cognitif } \\
\text { untuk } \\
\text { mengaitkan } \\
\text { faktor yang } \\
\text { diketahui }\end{array}$ & $\begin{array}{l}\text { Mampu } \\
\text { menyelesaikan } \\
\text { berdasarkan } \\
\text { rancangan yang } \\
\text { sudah dibuat }\end{array}$ \\
\hline & $(a+b)^{2}=a^{2}+b^{2}$ & $\begin{array}{l}\text { Hilangya tahap } \\
\text { kontrol terhadap } \\
\text { langkah-langkah } \\
\text { yang dilakukan }\end{array}$ & $\begin{array}{l}\text { Pemberian } \\
\text { conflict } \\
\text { cognitive } \\
\text { mengaikatn } \\
\text { langkah yang } \\
\text { diketahuti }\end{array}$ & $\begin{array}{l}\text { Mampu } \\
\text { menyelesaikan } \\
\text { berdasarkan } \\
\text { rancangan yang } \\
\text { sudah dibuat }\end{array}$ \\
\hline & $\sqrt{x+y}=\sqrt{x}+\sqrt{y}$ & $\begin{array}{l}\text { Hilangya tahap } \\
\text { kontrol terhadap } \\
\text { langkah-langkah } \\
\text { yang dilakukan }\end{array}$ & $\begin{array}{l}\text { Pemberian } \\
\text { conflict } \\
\text { cognitive } \\
\text { mengaikatn } \\
\text { langkah yang } \\
\text { diketahuti }\end{array}$ & $\begin{array}{l}\text { Mampu } \\
\text { mengaitkan } \\
\text { apaya yang } \\
\text { diketahui untuk } \\
\text { menentukan } \\
\text { langhkah solusi }\end{array}$ \\
\hline \multirow[t]{2}{*}{$\begin{array}{l}\text { Memeriksa } \\
\text { kembali solusi } \\
\text { yang diperoleh }\end{array}$} & $3 x 2+2=3 x(2+2)$ & $\begin{array}{lr}\text { Respon } & \text { terhdap } \\
\text { hasil } & \text { yang } \\
\text { diperoleh } & \text { secara } \\
\text { brutal } & \end{array}$ & $\begin{array}{l}\text { Pemberian } \\
\text { disequilibrasi } \\
\text { sebelum } \\
\text { mencapai } \\
\text { kondisi tidak } \\
\text { pseudo }\end{array}$ & $\begin{array}{l}\text { Mampu melihat } \\
\text { kembali jawaban } \\
\text { dengan konsep } \\
\text { terstrukstur }\end{array}$ \\
\hline & $(a+b)^{2}=a^{2}+b^{2}$ & \begin{tabular}{l}
\multicolumn{2}{l}{ Mengalami } \\
pseudo berpikir \\
karena faktor \\
kebiasaan
\end{tabular} & $\begin{array}{l}\text { Pemberian } \\
\text { diseguilibrasi } \\
\text { setelaha tiga } \\
\text { tahapa } \\
\text { sebelumya }\end{array}$ & $\begin{array}{l}\text { Mampu } \\
\text { memerksa } \\
\text { kembali jawaban } \\
\text { sesuai dengan } \\
\text { konsep yang } \\
\text { terstrukstur }\end{array}$ \\
\hline
\end{tabular}


DOI: https://doi.org/10.24127/ajpm.v9i3.2956

\begin{tabular}{|c|c|c|c|c|}
\hline \multirow{3}{*}{ Tahapan polya } & \multirow{2}{*}{ Soal } & \multicolumn{3}{|c|}{ Berpikir pseudo dan defragmenting } \\
\hline & & Pseudo & Defragmenting & Hasil \\
\hline & $\sqrt{x+y}=\sqrt{x}+\sqrt{y}$ & $\begin{array}{l}\text { Mengalami } \\
\text { pseudo berpikir } \\
\text { karena konsep } \\
\text { yang sederhana }\end{array}$ & $\begin{array}{l}\text { Pemberian } \\
\text { diseguilibrasi } \\
\text { setelaha tiga } \\
\text { tahapa } \\
\text { sebelumya }\end{array}$ & $\begin{array}{l}\text { Mampu } \\
\text { memerksa } \\
\text { kembali jawaban } \\
\text { sesuai dengan } \\
\text { konsep yang } \\
\text { terstrukstur }\end{array}$ \\
\hline
\end{tabular}

Pada Tabel 2 ditunjukkan bahwa hasil defragmenting proses berpikir pseudo konsep matematika siswa pada tiga soal tersebut, berdasarkan tahapan polya yaitu pada tahapan pertama dalam memahami masalah siswa lebih banyak mengalami kesalahan berpikir mengkontruksi konsep dan berpikir analogi, siswa hanya memahami secara dangkal dan sederhana. Kesalahan yang dialami siswa kemudian di defragmenting dengan pemberian scaffolding sehingga hasilnya siswa dapat mengungkap kembali kontruksi konsep dan kesalahan analogi secara tepat.

Tahapan kedua dalam merencanakan pemecahan masalah siswa kurang memahami konsep prasyarat serta prosedur dalam menjawab soal sehingga terjadi kesalahan dalam penempatan konsep. Namun setelah di defragmenting dengan pemberian scaffolding konsep prasyarat dan prosedur maka hasilnya siswa mampu merancang penyelesaian dengan baik dan benar.

Tahapan ketiga melaksanakan perencanaan pemecahan masalah siswa mengalami hilangnya kontrol dan mudah putuh asa karena kurangnya komitmen kognitif siswa. Namun dengan pemberiaan conflict cognitive dengan mengaitkan antar konsep maka hasilnya siswa dapat menyelesaikan soal berdasarkan rancangan yang sudah dibuat.
Tahapan keempat memeriksa kembali solusi yang diperoleh siswa, kesalahan terjadi ketika siswa menganggap konsep sederhana tersebut benar secara semu. Namun di defragmenting dengan pemberian disequilibrasi hasilnya siswa mampu memeriksa kembali jawaban dengan konsep yang terstruktur dan tepat.

Tahapan defragmenting dilakukan dengan pemberian scaffolding kepada siswa yang mengalami pseudo salah dalam memahami masalah dan merencanakan pemecahan masalah, mampu merekontruksi kembali pemahaman konsep siswa (Prayitno et al., 2018). Defragmenting dengan pemberian conflict cognitive bagi siswa dalam melaksanakan perencanaan penyelesaian masalah dapat membantu siswa merancang kembali penyelesaian masalah yang dihadapi (Aisya et al., 2019). Serta pemberian disequilibrasi pada siswa terhadap jawaban yang telah diberikan membuat siswa memerikan kembali solusi yang diperoleh sehingga mampu memberikan jawaban sesuai dengan konsep yang terstruktur (Rochayati \& Fa'ani, 2019).

Dari kegiatan tersebut terlihat bahwa terjadi proses berpikir pseudo salah pada siswa. Hal ini sejalan dengan penelitian (Vinner, 1997) bahwa kesalahan berpikir konsep matematika berpikir pseudo benar atau salah. Pseudo benar ketika jawaban siswa benar namun salah memberikan alasannya. Sedangkan pseudo salah 
terjadi ketika jawaban siswa salah namun setelah refleksi siswa mampu memberikan jawaban yang benar. Sebenarnya siswa dapat menyelesaikan masalah dengan benar namun seringkali dilakukan secara spontan, samar dan tidak terkontrol sehingga ketika dilakukan refleksi, siswa dapat memperbaiki dengan benar. Inilah kemudian menunjukkan proses berpikir semu (Subanji \& Toto, 2013).

Oleh karena itu, implikasi dari penelitian ini mampu mengembangkan proses pembelajaran secara utuh dengan alur konsep yang benar, lebih percaya diri dan mampu memeriksa kembali jawaban terkonsep dan terstruktur sehingga berdampak pada peningkatan hasil belajar siswa.

\section{KESIMPULAN DAN SARAN}

Berdasarkan hasil penelitian dan pembahasan siswa mengalami Pseudo salah merupakan karakteristik dalam mengkontruksi konsep matamatika berpikir analogi dan menempatkan konsep matematika secara benar, serta tidak mampu melihat prasyarat yang dibutuhkan dalam menyelesaikan sebuah masalah. Respon siswa dalam memeriksa kembali solusi yang diperoleh cenderung brutal dan berpikir sederhana. Hal inlah yang menyebabkan siswa berpikir pseudo salah yang menganggap jawaban salah seolah-olah benar. Tahap defragmenting pada penelitian tersebut dengan menggunakan tahapan polya dapat diselesaikan dengan pemberian scaffolding, Conflict Cognitif dan desiquilibrasi dapat memberikan kelengkapan konsep struktur berpikir siswa yang mengalami pseudo berpikir. Melalui tahapan defragmenting ini akhirnya siswa dapat memahami masalah yang diberikan, Menyusun rencana penyelesaian, melaksanakan penyelesaian dan memeriksa kembali dengan alur dan konsep yang benar. Sehingga siswa terhindar dari proses berpikir pseudo benar atau salah.

Adapun saran untuk penelitian selanjutnya, hendaknya penelitian tentang proses berpikir pseudo dilakukan lebih luas dan penelitian dilakukan pada jenjang SMA dan menggunakan tahapan berbeda selain tahapan polya.

\section{DAFTAR PUSTAKA}

Aisya, S., Kusaeri, \& Sutini. (2019). Restrukturisasi berpikir siswa melalui pemunculan skema dalam menyelesaikan soal ujian nasional mata pelajaran matematika. Jurnal Review Pembelajaran Matematika, 4(2), 43-56.

Badaruddin, Kadir, \& Anggo, M. (2016). Analisis Kesalahan dalam Menyelesaikan Soal-soal Operasi Hitung Pecahan pad Siswa Kelas VII SMP Negeri 10 Kendari. Jurnal Penelitian Pendidikan Matematika, 5(1), 99-113.

Haryanti, S. (2018). Pemecahan Masalah Matematika melalui Metode Defragmenting. JKPM (Jurnal Kajian Pendidikan Matematika), 3(2), 199. https://doi.org/10.30998/jkpm.v3i2 .2768

Indri, H. Y., \& Widiyastuti, E. (2018). Analisis Berpikir Pseudo Dalam Memecahkan Masalah Matematika. AlphaMath: Journal of Mathematics Education, 4(2), 61.

https://doi.org/10.30595/alphamath .v4i2.7634 
DOI: https://doi.org/10.24127/ajpm.v9i3.2956

Kennedy, M. L. (2008). Guiding Children's Learning of Mathematics. Courier Corporation.

Kirnasari, T. P., As'ari, A. R., \& Irawati, S. (2016). Defragmenting struktur berpikir untuk memperbaiki kesalahan siswa dalam memecahkan masalah persamaan kuadrat. Jurnal Pembelajaran Matematika, 3(2), 128-138.

Ormrod, J. E. (2009). Psikologi Pendidikan Membantu Siswa Tumbuh dan Berkembang. Erlangga.

Prayitno, A., Kaka, R., \& Hamid, A. (2018). Pemberian Scaffolding Berdasarkan Kesalahan Matematika. 3(2), 161-172.

Pujilestari. (2018). Analisis Kesalahan Siswa Dalam Menyelesaikan Soal Matematika Sma Materi Operasi Aljabar Bentuk Pangkat Dan Akar. Jisp, 2(1), 226-232.

Rochayati, M. Y., \& Fa'ani, A. M. (2019). Defragmenting struktur berpikir siswa dalam menyelesaikan masalah analogi. Proceeding of International Confrence on Islamic Education: Challenges in Technology and LiteracyFaculty of Education and Teacher Training, Universitas Islam Negeri Maulana Malik Ibrahim Malang, 321-330.

Siswandi, E. (2016). Analisis kesalahan siswa dalam menyelesaikan masalah matematika konstektual pada materi segiempat berdasarkan analisis newman ditinjau dari perbedaan gender. Jurnal
Elektronik Pembelajaran Matematika, 4(7), 633-643.

Sopamena, P., Mastuti, A. G., \& Hukom, J. (2018). Analisis Kesalahan Berpikir Pseudo Siswa dalam Mengkonstruksi Konsep Limit Fungsi Pada Siswa Kelas XII IPA SMA Negeri 11 Ambon. Prosiding SEMNAS Matematika \& Pendidikan Matematika IAIN Ambon, Februari, 209-215.

Subanji, S., \& Nusantara, T. (2016). No TitleThinking Process of Pseudo Construction in Mathematics Concepts. International Education Studies, 9(2), 17-31.

Subanji, \& Toto. (2013). Karakteristik Kesalahan Berpikir Siswa dalam Mengkonstruksi Konsep Matematika. Jurnal Ilmu Pendidikan, 19(2), 208-211.

Vilianti, Y. C., Pratama, F. W., \& Mampouw, H. L. (2018). Description of The Ability of Social Arithedical Stories by Study Problems by Students VIII SMP Reviewed from The Polya Stage. International Journal of Active Learning, 3(1), 23-32.

Vinner, S. (1997). The pseudoconceptual and the pseudoanalytical thought processes in mathematics Learning. Educational Studies in Mathematics, 34, 97-129.

Wibawa, K. A., Nusantara, T., Subanji, S., \& Parta, I. N. (2017). Fragmentation of Thinking Structure's Students to Solving the Problem of Application Definite Integral in Area. International 
DOI: https://doi.org/10.24127/ajpm.v9i3.2956

Education Studies, 10(5), 48. https://doi.org/10.5539/ies.v10n5p 48

Wibowo, T., Purwoko, R. Y., \& Swaraswati, T. (2018). Analisis Berpikir Pseudo Siswa Dalam. Jurnal Review Pembelajaran Matematika, 4(2), 115-127.

Wulandari, T. (2018). Analisis kesalahan siswa dalam menyelesaikan soal pada materi lingkaran. Jurnal Pendidikan Tembusai, 2(6), 1693-1697.

Yani, M., Ikhsan, M., \& Marwan. (2016). Proses Berpikir Siswa Sekolah Menengah Pertama Dalam Memecahkan Masalah Matematika Berdasarkanlangkah-Langkah Polya. Jurnal Pendidikan Matematika, 10(1), 43-58.

Yuwono, T., Supanggih, M., \& Ferdiani, R. D. (2018). Analisis Kemampuan Pemecahan Masalah Matematika dalam Menyelesaikan Soal Cerita Berdasarkan Prosedur Polya. Jurnal Tadris Matematika, 1(2), 137-144. https://doi.org/10.21274/jtm.2018. 1.2.137-144 